\title{
Glioma malignancy is linked to interdependent and inverse AMOG and L1 adhesion molecule expression
}

\author{
Qiong Jiang ${ }^{1}$, Qing Xie ${ }^{1}$, Chengliang Hu${ }^{1}$, Zhai Yang ${ }^{1}$, Peizhi Huang ${ }^{1}$, Huifan Shen ${ }^{1}$, Melitta Schachner ${ }^{1,2^{*}}$ and \\ Weijiang Zhao ${ }^{1 *}$ (D)
}

\begin{abstract}
Background: Gliomas account for the majority of primary human brain tumors and remain a challenging neoplasm for cure due to limited therapeutic options. Cell adhesion molecules play pivotal roles in the growth and progression of glial tumors. Roles of the adhesion molecules on glia (AMOG) and L1CAM (L1) in glioma cells have been shown to correlate with tumorigenesis: Increased expression of L1 and decreased expression of AMOG correlate with degree of malignancy.

Methods: We evaluated the interdependence in expression of these molecules by investigating the role of AMOG in vitro via modulation of L1 expression and analyzing apoptosis and cell senescence of glioma cells.

Results: Immunohistochemical staining of normal human cortical and glioma tissue microarrays demonstrated that AMOG expression was lower in human gliomas compared to normal tissue and is inversely correlated with the degree of malignancy. Moreover, reduction of AMOG expression in human glioblastoma cells elevated L1 expression, which is accompanied by decreased cell apoptosis as well as senescence.

Conclusion: AMOG and L1 interdependently regulate their expression levels not only in U-87 MG cells but also in U251 and SHG44 human glioma cell lines. The capacity of AMOG to reduce L1 expression suggests that methods for increasing AMOG expression may provide a therapeutic choice for the management of glial tumors with high expression of L1.
\end{abstract}

Keywords: Glioma, AMOG, L1CAM, Apoptosis, Senescence, Therapy, Human

\section{Background}

Glioma is a brain neoplasm mainly originating from glial cells. It accounts for about $30 \%$ of all tumors in the human central nervous system and about $80 \%$ of the malignant ones $[1,2]$. Glial tumors are characterized by infiltrative growth behavior, high proliferative potential, intratumoral heterogeneity, and recurrence. They are graded from I to IV according to the criteria of the World Health Organization (WHO). In existing practice, treatment of gliomas mainly includes surgical resection, radiotherapy and chemotherapy. However, these regimens are often not

\footnotetext{
*Correspondence: schachner@stu.edu.cn; schachner@dls.rutgers.edu; weijiangnsc@163.com

${ }^{1}$ Center for Neuroscience, Shantou University Medical College, 22 Xin Ling Road, Shantou, Guangdong 515041, People's Republic of China

Full list of author information is available at the end of the article
}

successful in the management of gliomas and lead to recurrence and progression to malignancy. It appears, therefore, necessary to identify the molecular players involved in the development and progression of glioma malignancy [1].

Several cell adhesion molecules have been identified to underlie the occurrence of malignancies in gliomas, including adhesion molecule on glia (AMOG) [3] and neural cell adhesion molecule L1 (L1CAM, hereafter abbreviated L1) $[4,5]$. AMOG was first identified as an integral membrane glycoprotein highly expressed by astrocytes and shown to mediate the interaction between neurons and astrocytes $[3,6]$ and thereafter identified to be the $\beta 2$-subunit of $\mathrm{Na}^{+} / \mathrm{K}^{+}$-ATPase, based on genomic structure and cDNA sequence [7-10]. Another study had also shown that AMOG enhances neurite outgrowth of cultured cerebellar and hippocampal neurons [11]. In addition,

(c) The Author(s). 2019 Open Access This article is distributed under the terms of the Creative Commons Attribution 4.0 International License (http://creativecommons.org/licenses/by/4.0/), which permits unrestricted use, distribution, and reproduction in any medium, provided you give appropriate credit to the original author(s) and the source, provide a link to the Creative Commons license, and indicate if changes were made. The Creative Commons Public Domain Dedication waiver (http://creativecommons.org/publicdomain/zero/1.0/) applies to the data made available in this article, unless otherwise stated. 
overexpression of AMOG increases adhesion on Matrigel and decreases migration of glioma cells in vitro [12]. In human glioblastoma cell cultures captured from surgical specimens, enhanced levels of AMOG expression correlated positively with invasion without affecting migration or proliferation, and knock-down of AMOG expression promoted cell migration in cultures of human astrocytes [13].

Neural cell adhesion molecule L1 also plays a crucial role in glioma tumor progression. L1 is a transmembrane glycoprotein of the immunoglobulin superfamily and important in development, synaptic activity and regeneration after trauma [14]. Through interacting with itself and other cell adhesion molecules in homophilic and heterophilic binding mechanisms, L1 promotes glioma cell migration, invasion and metastasis. Elevated L1 expression was observed in cultured glioblastoma and neuroblastoma cells [15] who showed activation of two signaling pathways, the extrinsic and the intrinsic pathway, which are considered to be potential therapeutic targets that could lead to inhibition of development and progression of malignancy $[16,17]$. Thus, insights into the molecular mechanisms underlying malignancy, apoptosis and senescence are important goals in the development of new and more effective treatments.

Based on the knowledge of L1 functions and AMOG in tumor progression, with AMOG being weakly and L1 highly expressed in high-grade gliomas, we hypothesized that there may be a functional link between AMOG and L1 expression and function in the context of glioma metastasis. We now show that down-regulation of AMOG expression is accompanied by increased L1 expression as well as cell senescence and apoptosis. Vice versa, downregulation of L1 expression leads to increased AMOG expression. The functional link between AMOG and L1 was shown to be differentially involved in apoptosis via the AKT and ERK signaling pathways in three human glial cell lines in vitro.

\section{Methods}

\section{Cell culture}

The human glioblastoma U-87 MG (catalog no. CL0238) and human glioma U251 (catalog no. CL_0237) cell lines were purchased from Procell Life Science \& Technology Co., Ltd. (Wuhan, China) in April 2018. The human glioma SHG-44 (catalog no. SHG44) cell line was purchased from Guangzhou Jennio Biotech Co., Ltd.
(Guangzhou, China). All cell lines were recently authenticated by short tandem repeat (STR) analysis and tested for mycoplasma contamination. After being delivered, cell lines were maintained in Dulbecco's modified Eagle's medium (DMEM, HyClone ${ }^{\mathrm{rm}}$; Thermo Fisher Scientific, catalog no. 11330032, Beijing, China) supplemented with $50 \mathrm{U} / \mathrm{mL}$ of a penicillin/streptomycin mixture (Solarbio, catalog no. P1400, Beijing, China) and 10\% fetal bovine serum (FBS, Sijiqing Biotech, catalog no. 11011-6125, Hangzhou, China). Cells were maintained in $75-\mathrm{cm}^{2}$ cell culture dishes (Jet Bio-Fil, catalog no. TCD010100, Guangzhou, China) at $37^{\circ} \mathrm{C}$ in a humidified $5 \%$ carbon dioxide atmosphere.

\section{Reagents and tissue microarray}

Recombinant human L1CAM (rL1, Sino Biological, cata$\log$ no. 10140-H08H, Beijing, China) was dissolved in PBS as the stock solution $(100 \mu \mathrm{g} / \mathrm{mL})$ in accordance with the manufacturer's instructions. Control siRNA, L1 siRNA and AMOG siRNA are listed in Table 1. For over-expression of human AMOG, a commercial control plasmid (pCMV3-C-GFPSpark, Sino Biological, catalog no. CV026, Beijing, China) and a human green fluorescent protein (GFP) labeled AMOG plasmid (pCMV3-AMOGGFPSpark, catalog no. HG15882-AG, Sino Biological) were used. Lipofectamine 2000 reagent was obtained from Invitrogen (catalog no. 11668019) and was utilized in cell transfection following the manufacturer's instructions. Twenty-four hours after transfection, cells were maintained for another $24 \mathrm{~h}$ and treated with hygromycin B (Solarbio, catalog no. 10843555001) at a concentration of $500 \mu \mathrm{g} / \mathrm{mL}$ for the following passages. Transfection efficiency was calculated by estimating the percentage of GFP-fluorescent cells over the numbers of all total cells (set at $100 \%$ ).

A total of 208 cases of human cerebral tissues and one skin tissue were included in the brain glioma tissue microarray containing formalin-fixed paraffin-embedded $5-\mu \mathrm{m}$ thick sections from human glioma and normal cerebral cortex (US Biomax, GL2083a, Derwood, MD, USA). Brain glioma tissue microarray consists of samples from different donor tissues that had been evaluated by a certified neuropathologist and scored on a scale of I to IV based on the WHO grading system as follows: tumor-adjacent normal brain tissue and normal brain tissue $(n=18)$, pilocytic astrocytoma (WHO grade I, $n=23)$, WHO grade I-II ( $n=$ 19), diffuse astrocytoma (WHO grade II, $n=85$ ), anaplastic

Table 1 Sequences of control siRNA, L1 siRNA and AMOG siRNA

\begin{tabular}{|c|c|c|}
\hline Reagent & Sense strand sequences & Anti-sense strand sequences \\
\hline Control siRNA & 5'-UUCUCCGAACGUGUCACGUTT-3' & 3'-TTAAGAGGCUUGCACAGUGCA-5' \\
\hline AMOG siRNA & 5'-GAGCCUUACAACGACUCUATT-3' & 3'-TTCUCGGAAUGUUGCUGAGAU-5' \\
\hline L1 siRNA & 5'-GCAUUAGUGGCCAUCCUUUTT - 3' & 3'-TTCGUAAUCACCGGUAGGAAA-5' \\
\hline
\end{tabular}


astrocytoma (WHO grade III, $n=27$ ), and glioblastoma (WHO grade IV, $n=31$ ).

\section{Immunohistochemistry}

The microarray was deparaffinized, rehydrated via a graded series of ethanol to PBS. Antigen retrieval was performed with $10 \mathrm{mmol} / \mathrm{L}$ citrate buffer $(\mathrm{pH} \mathrm{6.0)}$ ) for 40 min at $99^{\circ} \mathrm{C}$. The sections were then incubated in $3 \%$ $\mathrm{H}_{2} \mathrm{O}_{2}$ solution to block endogenous peroxidase activity, followed by incubation with $10 \%$ non-immune goat serum for $30 \mathrm{~min}$. Sections were incubated with rabbit polyclonal anti-ATP1B2/AMOG antibody (Thermo Scientific, catalog no. PA5-26279, 1:50, Rockford, USA) overnight at $4{ }^{\circ} \mathrm{C}$ PBS and incubated with biotinylated secondary antibody, and streptavidin-peroxidase conjugate according to the manufacturer's instructions (Zhong Shan Golden Bridge Biotechnology, catalog no. PV-9000-D, Beijing, China). Enzyme activity was developed using the AEC kit (Zhong Shan Golden Bridge Biotechnology, catalog no. ZLI-9036). The sections were mounted in aqueous mounting medium (Boster, catalog no. AR1018, Pleasanton, USA).

Integrated immunostaining intensity was evaluated by digital scanning using a flashing camera (Sony, DSCW210,). Optical density of immunostainings was evaluated using a gel imaging system and Fluochem Software (Alpha Innotech, San Leandro, CA, USA). The integrated staining intensity was evaluated on the basis of a gray scale ranging from 0 to 255 and expressed as the fold increase over the normal brain tissue sample. Images were captured with a digital microscope (Ningbo Yongxin Optics, NOVEL, DN-10, Jiangsu, China).

\section{Cell senescence assay}

U-87 MG cells were seeded at a density of $1 \times 10^{4}$ cells per well in 8-well chamber slides or in 96-well cell culture plates in DMEM and 10\% fetal bovine serum and allowed to settle overnight. They were then transfected with AMOG siRNA or control siRNA, and then assayed after $48 \mathrm{~h}$ for X-Gal staining by an overnight incubation at $37^{\circ} \mathrm{C}$, according to the manufacturer's protocol (Beyotime Biotech, cat no. C0602). Images of 9 corresponding areas were captured light microscopically. For the measurement of $\beta$-galactosidase activity, cells were digested with red blood cell lysis buffer (cat no. C3702, Beyotime Biotech) and absorbance of X-Gal reaction product was measured with a microplate reader (Infinite M1000, Tecan, Männedorf, Switzerland).

\section{Effects of AMOG on L1 expression}

AMOG siRNA was used to evaluate the effect of AMOG on L1 expression levels, with control siRNA used as the control. U-87 MG, U251 and SHG-44 cells were tested at $60-80 \%$ confluence. The culture medium was then aspirated, replaced with fresh medium containing $200 \mu \mathrm{L}$ siRNA-mate complexes or $0.2 \mu \mathrm{L}$ Lipofectamine 2000 transfection reagent for $48 \mathrm{~h}$ at $10 \mathrm{nmol} / \mathrm{L}$ siRNA and thereafter maintained for $48 \mathrm{~h}$.

\section{Effects of L1 on AMOG expression}

Out three L1 siRNAs the most efficient one was tested with U-87 MG, U251 and SHG-44 cells for its effect on AMOG expression under the conditions described for AMOG siRNA. In addition, the influence of recombinant human L1 extracellular domain on AMOG expression was tested by a $48 \mathrm{~h}$ incubation of cells with rL1 at $0,1.0,2.5,5.0$ and $10 \mathrm{nmol} / \mathrm{L}$. AMOG expression was determined by Western blot analysis and immunofluorescence staining.

\section{Western blot analysis}

Western blot analysis was performed as described [15] with antibodies listed in Table 2. Antigens were visualized using an enhanced chemilluminescence (ECL) solution (Beyotime Biotech). The signal intensity was quantified using Image J software (version 1.48, rsb.info.nih.gov/ij/) as average densitometric value multiplied by the area (measured as the number of pixels).

Table 2 Antibodies used for Western blot analysis

\begin{tabular}{|c|c|c|c|c|}
\hline Antibody & Species & Cat. no. & Dilutions & Manufacture \\
\hline L1 & mouse monoclonal & MAB777 & $1: 1000$ & R\&D Systems \\
\hline AMOG/ATP1B2 & rabbit polyclonal & PA5-26279 & $1: 1000$ & Thermo Scientific \\
\hline p-Akt1/2/3 (11E6) & mouse monoclonal & sc- 81,433 & $1: 1000$ & Santa Cruz \\
\hline Akt1 (G-5) & monoclonal mouse & sc- 55,523 & $1: 1000$ & Santa Cruz \\
\hline $\mathrm{p}-\mathrm{Erk} 1 / 2(\mathrm{E}-4)$ & monoclonal mouse & sc-7383 & $1: 1000$ & Santa Cruz \\
\hline Erk1/2 (MK1) & monoclonal mouse & sc- 135,900 & $1: 1000$ & Santa Cruz \\
\hline $\operatorname{Bax}(P-19)$ & polyclonal rabbit & sc-526 & $1: 1000$ & Santa Cruz \\
\hline $\mathrm{BCl}-2(\mathrm{C}-2)$ & monoclonal mouse & sc-7382 & $1: 1000$ & Santa Cruz \\
\hline GAPDH (G-9) & monoclonal mouse & sc- $3,650,620$ & $1: 1000$ & Santa Cruz \\
\hline B-Actin (C4) & monoclonal mouse & sc- 47,778 & $1: 1000$ & Santa Cruz \\
\hline
\end{tabular}




\section{Immunofluorescence staining}

Cells were seeded at a density of $1 \times 10^{4}$ cells per well in an 8-chamber plate. After an overnight incubation, the cells were treated with L1 siRNA at $0,5,10$ or $20 \mathrm{nM}$ for $48 \mathrm{~h}$. Cells were then fixed with $4 \%$ formaldehyde in PBS for $15 \mathrm{~min}$, blocked with normal donkey serum and incubated overnight at $4{ }^{\circ} \mathrm{C}$ with monoclonal mouse anti-human L1 antibody (R\&D Systems, MAB777, 1:200) or polyclonal rabbit anti-human ATP1B2/AMOG antibody (Thermo Scientific, PA5-26279, 1:200). Corresponding

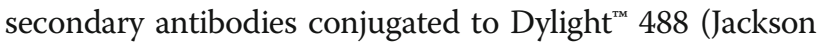
ImmunoResearch, 715-485-150, 1: 500) and Dylight ${ }^{\mathrm{TM}} 594$ (Jackson ImmunoResearch, 711-515-152, 1: 500). Slides were mounted in ProLong ${ }^{\circledR}$ Gold Antifade reagent with DAPI (Life Technologies, ThermoFisher Scientific, P36935). Double-immunofluorescence images were acquired with laser confocal laser microscopy (Olympus, FV-1000) in a multi-track configuration.

\section{Statistics}

Statistical analyses were performed with SPSS17.0 software (IBM, Armonk, New York, USA) and GraphPad Prism 7 (GraphPad, Los Angeles, CA, USA). Values are expressed as means \pm SEM and analyzed by one-way ANOVA with Tukey's post-hoc test for dependent samples or with the Student's $t$-test for independent samples. Differences were considered statistically significant at $* p<0.05,{ }^{* * *} p<0.01$ and $* * * 0.001$.

\section{Results}

\section{AMOG expression in human glioma tissue microarray}

A tissue microarray was subjected to immunohistochemical staining of AMOG on normal brain tissue (both tumor-adjacent normal brain tissue and grey matter tissue from normal brain) and glioma tissues of different WHO grades. A light microscopic image of the AMOGimmunostained microarray was taken (Fig. 1a), and the black-and-white image of each tissue sample was generated by a gel imaging system and Fluochem software (Fig. 1b). Each tissue sample was rated and pooled according to the grade classification (Fig. 1c). As compared to the normal group, AMOG immunostaining intensities were considerably lower in the glioma tissue groups $(p=0.23,0.019,<0.000,<0.000$, and $<0.000$ for grades I, I-II, II, III and IV, respectively). Intensities decreased from grade I to IV $(p=0.28,<0.007$ and $<0.004$, respectively, versus grade I glioma; Fig. 1d). Representative immunohistochemical images of AMOG in normal human brain and different grades of human glioma tissues are shown at different magnifications (Fig. 1e). In summary, AMOG expression decreases with increasing tumor grade.
AMOG siRNA increases L1 expression and reduces cell senescence and apoptosis in glioma cells

Erk and Akt signaling pathways contribute to cell migration, metastasis, senescence, and apoptosis in human glioma cells [18]. Bax and Bcl-2 are master regulators of apoptosis promotion and inhibition, respectively, and they are also regulated by the Erk and Akt. We then asked whether AMOG siRNA would affect L1 expression via signaling these molecules. AMOG siRNA reduced AMOG expression $(p=0.0041)$ and increased L1 expression $(p=0.0029)$ in comparison to the Control siRNA group in U-87 MG cells (Fig. 2a). Akt1 and Erk1/ 2 phosphorylation levels were increased in the AMOG siRNA group ( $p=0.0154$ for pAkt1/Akt1 levels, and $p=$ 0.0002 for $\mathrm{pErk} 1 / 2 /$ Erk1/2 levels, versus Control siRNA; Fig. 2b, c). AMOG siRNA decreased the ratio of Bcl-2/ $\operatorname{Bax}(p=0.0173$ versus Control siRNA, Fig. $2 \mathrm{~d})$. Taken together, reduction of AMOG expression increases L1 expression, in parallel with elevated levels of pErk and pAkt, and AMOG decreases the Bcl-2/Bax ratio in parallel with increased apoptosis.

To investigate whether reduction of AMOG expression leads to cell senescence, $\beta$-galactosidase activity was measured. After challenging with AMOG siRNA or Control siRNA for $48 \mathrm{~h}, \mathrm{U}-87 \mathrm{MG}$ cells were evaluated via the $\beta$ galactosidase $\mathrm{X}-\mathrm{Gal}$ substrate. $\beta$-galactosidase activity was reduced in the group treated with AMOG siRNA as compared with the Control group as seen with single cells (Fig. 2e) and cell aggregates (Fig. 2f). Optical density values in the AMOG siRNA group were lower than in the Control siRNA group $(p<0.0001$ versus Control siRNA, Fig. $2 \mathrm{~g}$ ), indicating that reduction of AMOG expression ameliorates glioma cell senescence in vitro.

\section{L1 siRNA increases AMOG expression in three glioma cell lines}

Since AMOG siRNA treatment increases L1 expression and reduces cell senescence, we asked whether L1 affects AMOG expression. As expected, L1 expression was reduced in U-87 MG, U251 and SHG44 cells treated with L1 siRNA $(p=0.023$ in U-87 MG cells, $p=0.002$ in U251 cells, and $p=0.043$ in SHG44 cells, versus control siRNA; Fig. 3a, b, c). This treatment enhanced AMOG expression $(p=0.017$ in U-87 MG cells, $p=0.01$ in U251 cells, and $p=0.11$ in SHG44 cells, versus control siRNA; Fig. 3a, b, c). Similar results for L1 and AMOG were obtained with 5, 10 and 20 nM L1 siRNA (Additional file 1: Figure S1a, b, c). In contrast to U-87 MG cells which shows one band for AMOG by Western blot analysis, two bands were detected in U251 and SHG44 cells. The bands between $45 \mathrm{kDa}$ and $65 \mathrm{kDa}$ represent the glycosylated and non-glycosylated forms of ATP1B2. A recent study [19] confirms our findings, showing two bands of AMOG between 35 and $70 \mathrm{kDa}$, representing 
a

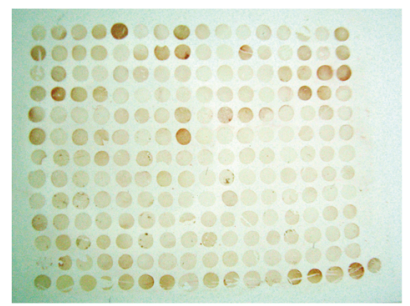

C

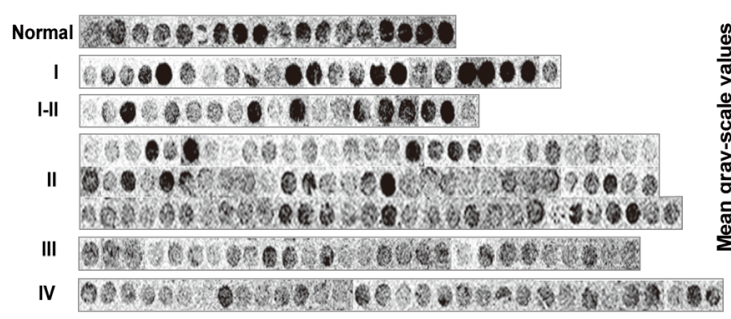

b

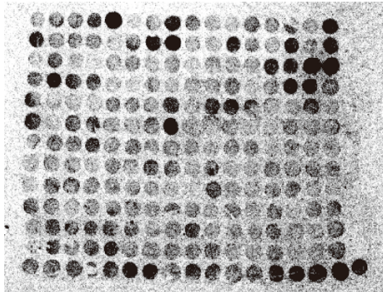

d

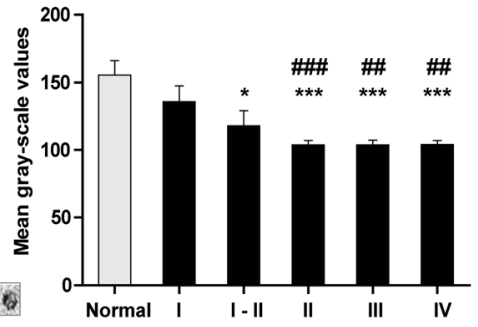

e

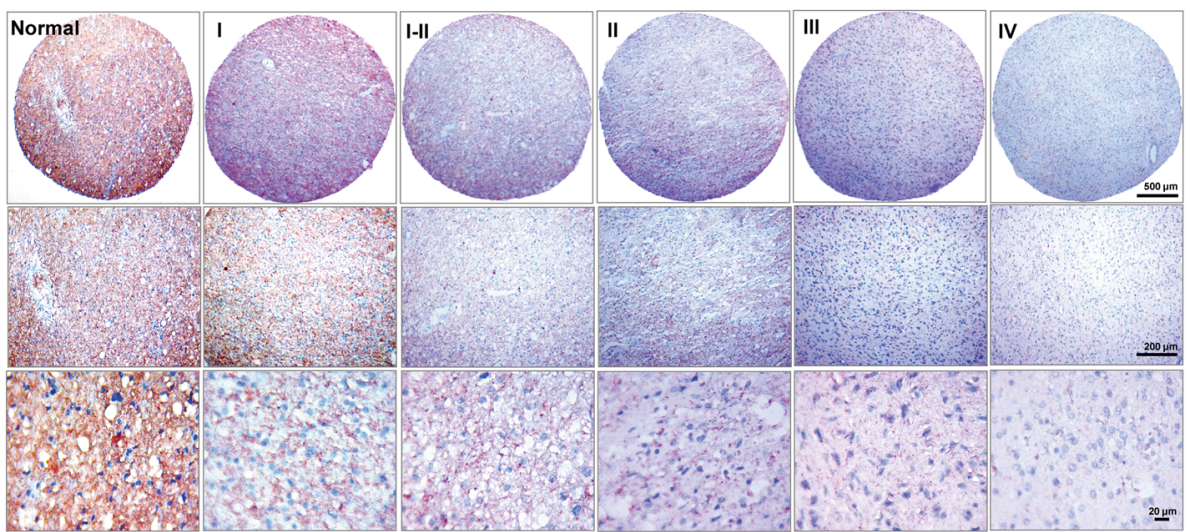

Fig. 1 AMOG expression as assayed in a normal human brain and glioma tissue microarray. a Immunostaining of AMOG in the microarray containing both tumor-adjacent normal human brain and glioma tissues graded from I to IV. b Gray-scale image showing AMOG expression in all samples. c Samples from the tissue microarray were pooled in accordance with the WHO grading system. d Data were collected from all the samples arrayed in the slides for quantification. Values are expressed as means $\pm \mathrm{SEM}$. ${ }^{*} p<0.05$, compared with normal brain tissues; ${ }^{*} p<0.05$, compared with grade I glioma tissues; one-way ANOVA with Tukey's post-hoc test. Samples of normal brain tissue $(n=18)$, pilocytic astrocytoma (WHO grade I, $n=23)$, WHO grade I-II ( $n=19)$, diffuse astrocytoma (WHO grade II, $n=85)$, anaplastic astrocytoma (WHO grade III, $n=27)$, and glioblastoma (WHO grade IV, $n=31$ ). e Representative AEC-based AMOG immunostained images in normal human brain tissues and different grades of human glioma tissues. Photographs were taken with a digital microscope. Scale bars, upper panels $500 \mu \mathrm{m}$, middle panels $200 \mu \mathrm{m}$, and lower panels $20 \mu \mathrm{m}$

both glycosylated and unglycosylated isoforms of AMOG in HEK293 cell.

In addition to Western blot analysis, double immunofluorescence staining of AMOG and L1 was performed in response to 5, 10 and $20 \mathrm{nML} 1$ siRNA application, which indicates that L1 siRNA increases AMOG expression (Fig. 3d, e, f, and Additional file 2: Figure S2a, b, c).

\section{L1 siRNA affects apoptosis-related signaling pathways in glioma cells}

Since signaling pathways are important features of a cell to influence cellular behavior, such as, for instance, migration, survival, senescence, and tumorigenesis, we tested paradigmatic such as pErk and pAkt, Bcl-2 and Bax. To this aim, L1 siRNA was applied to the glioma cells and Western blot analysis was performed to assay for these signal transducers. Compared to the Control siRNA group, L1 siRNA increased levels of pAkt1 and pErk1/2 (for U-87MG cells, $p=0.038$ in Fig. 4a for pAkt1 levels, and $p=0.016$; in Fig. $4 \mathrm{~b}$ for pErk1/2 levels. For U251 cells, $p=0.003$ in Fig. 4d for pAkt1 levels and $p=0.002$ in Fig. 4e for pErk1/2 levels. For SHG44 cells, $p=0.045$ in Fig. $4 \mathrm{~g}$ for pAkt1 levels, and $p=0.039$ in Fig. 4 h for pErk1/2 levels; all $p$ values refer to the Control siRNA). Interestingly, L1 siRNA did not affect 


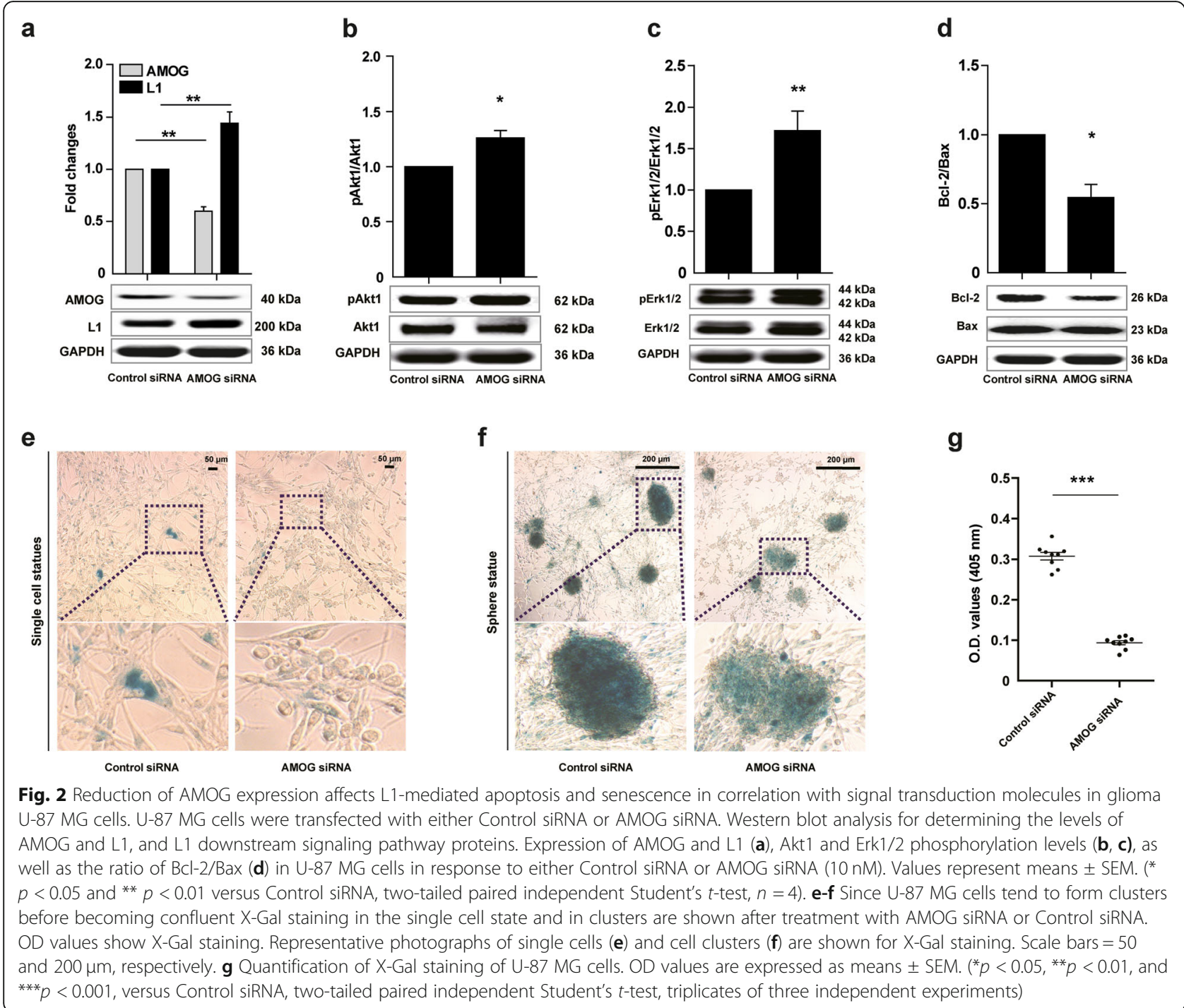

the $\mathrm{Bcl}-2 / \mathrm{Bax}$ ratio $(p=0.886$ versus Control siRNA for treatment of U-87 MG cells, Fig. 4c; $p=0.548$ versus Control siRNA for treatment of U251 cells Fig. 4f). However, the Bcl-2/Bax ratio in SHG44 cells was considerably reduced by treatment with $5 \mathrm{nML1}$ siRNA ( $p=0.002$ versus Control siRNA, Fig. 4i). To analyze whether these regulatory patterns on apoptosis-related signaling pathways would be different with higher concentrations of L1 siRNA, cells were treated with 10 and $20 \mathrm{nM}$ of L1 siRNA for $48 \mathrm{~h}$. Western blot analysis showed that suppressing L1 expression increased pAkt1 levels for in U-87 MG cells $(p=0.48$ and $p=0.005$ with 10 and $20 \mathrm{nML} 1$ siRNA, respectively, versus dose-matched Control siRNA, Additional file 3: Figure S3a). L1 siRNA at 10 and $20 \mathrm{nM}$ for U251 and SHG44 cells reduced pAkt1 levels when compared to Control siRNA $(p=0.917$ and $p=0.0487$, respectively, in U251 cells; $p=0.832$ and $p=0.002$, respectively, in SHG44 cells; Additional file 3: Figure S3d, g). pErk1/2 levels showed a similar trend as seen for pAkt1 (Additional file 3: Figure $\mathrm{S} 3 \mathrm{~b}, \mathrm{e}, \mathrm{h})$. The $\mathrm{Bcl}-2 / \mathrm{Bax}$ ratio was reduced in response to $20 \mathrm{nM}$ of L1 siRNA (Additional file 3: Figure S3c, f, i). Thus, reduction of $\mathrm{L} 1$ expression reduces the $\mathrm{Bcl}-2 / \mathrm{Bax}$ ratio, which is characteristic of apoptosis. The combined results indicate that L1 inversely regulates AMOG expression and contributes to reduction of apoptosis mainly via Erk and Akt signaling.

\section{L1 reduces AMOG expression and suppresses apoptosis in glioma cells}

Treatment of cells with recombinantly expressed extracellular domain of L1 (rL1) dose-dependently increased L1 levels in U251 and SHG44 cells (1, 2.5, 5 and $10 \mathrm{nM}, p=$ $0.145, p=0.026, p<0.000$, and $p<0.000$ respectively, versus Control siRNA), and dose-dependently reduced AMOG levels in U-87 MG cells ( $p=0.140, p=0.001, p<$ 0.000 , and $p<0.000$ for $1,2.5,5$ and $10 \mathrm{nM}$, respectively, 

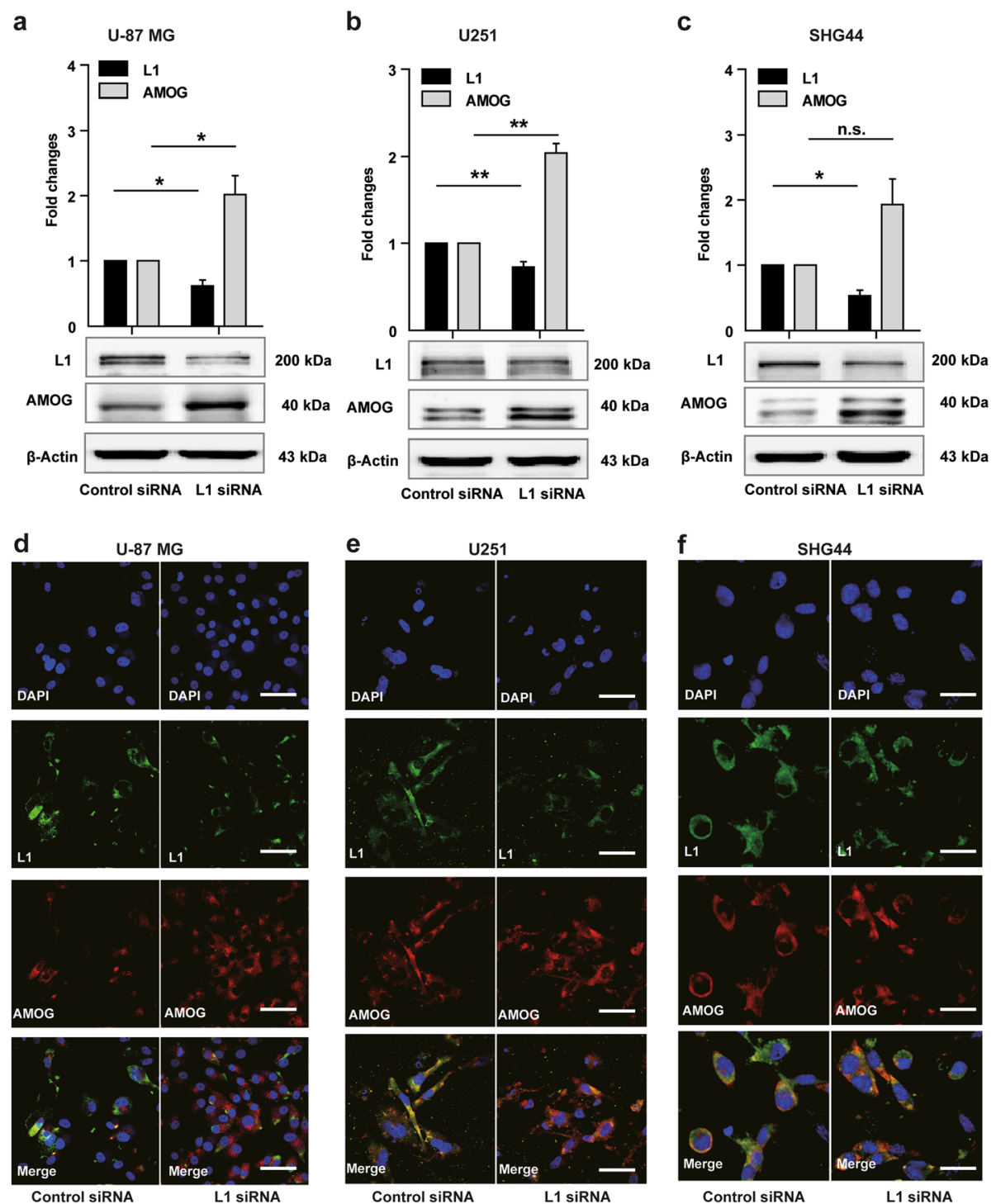

Fig. 3 Reduced L1 expression leads to elevated AMOG expression. a-c Western blot analysis of L1 and AMOG expression in U-87 MG (a), U251 (b), and SHG 44 (c) cells after treatment with L1 siRNA at $5 \mathrm{nM}$. Mean values \pm SEM from 4 independent experiments are presented. ${ }^{*} p<0.05$, ${ }^{* *} p<0.01,{ }^{* * *} p<0.001$ vs. Control siRNA, independent Student's $t$-test). $\mathbf{d}$-f Representative images of double immunofluorescence staining of $L 1$ and AMOG in response to L1 siRNA at $5 \mathrm{nM}$ in U-87 MG (d), U251 (e) and SHG44 (f) cells. Scale bars $=50 \mu \mathrm{m}$

versus Control siRNA, Fig. 5a). Similarly, L1 levels in U251 and SHG44 cells were also dose-dependently upregulated in comparison with Control siRNA (for 1, 2.5, 5 and $10 \mathrm{nM}, p=0.467, p=0.111, p=0.024, p<0.000$, respectively, versus Control siRNA in U251 cells, Fig. 5e; for $1,2.5,5$ and $10 \mathrm{nM}, p=0.189, p=0.028, p=0.024, p=$ 0.001 respectively, versus Control siRNA in SHG44 cells, Fig. 5i). Administration of $1.0 \mathrm{nM}$ rL1 to U251 and SHG44 cells increased AMOG levels $(p=0.001$ in U251 cells, Fig. 5e; $p=0.003$ in SHG44 cells, Fig. 5i), whereas AMOG expression was decreased with increasing concentrations of rL1 (for 2.5, 5, and $10 \mathrm{nM}, p=0.779, p=0.049$ and $p=0.018$, respectively, versus Control siRNA in U251 cells, Fig. 5e; $p=0.291, p=0.049$ and $p=0.019$ for 2.5, 5, and $10 \mathrm{nM}$, respectively, versus Control siRNA in SHG44 cells, Fig. 5i). rL1 reduced pAkt1 levels in a dosedependent manner in both U-87 MG and U251 cells (for $1,2.5,5$ and $10 \mathrm{nM}, p=0.008, p=0.001, p<0.000, p<$ 0.000 , respectively, versus Control siRNA, Fig. 5b; $p=$ 0.102, $p=0.021, p=0.004, p<0.000$, for $1,2.5,5$ and 10 $\mathrm{nM}$, respectively, versus Control siRNA, Fig. $5 \mathrm{f}$ ). In contrast, pAkt1 levels in SHG44 cell were dose-dependently increased at 1 and $2.5 \mathrm{nM}$ of $\mathrm{rL} 1(p=0.001$ and $p=0.094$, respectively), and thus reduced compared to control (for 5 and $10 \mathrm{nM}, p=0.033$ and $p=0.001$, respectively, versus Control siRNA, Fig. 5j). Similar to pAkt1 levels, pErk1/2 


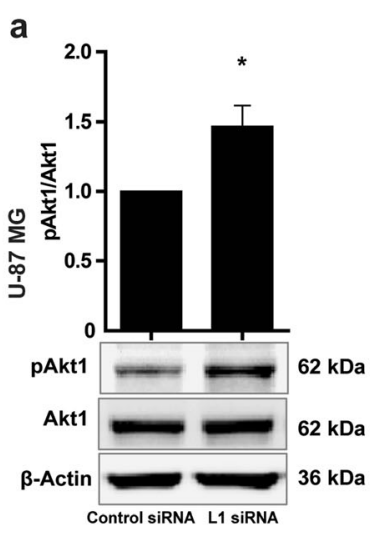

d

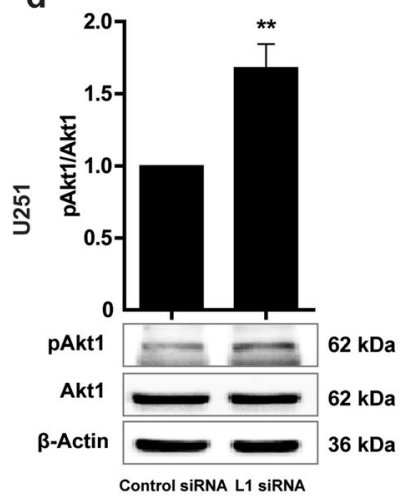

g

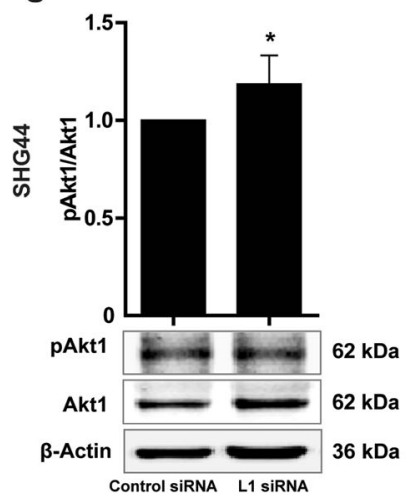

b
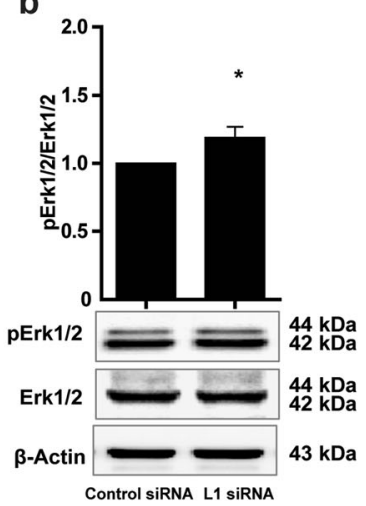

e

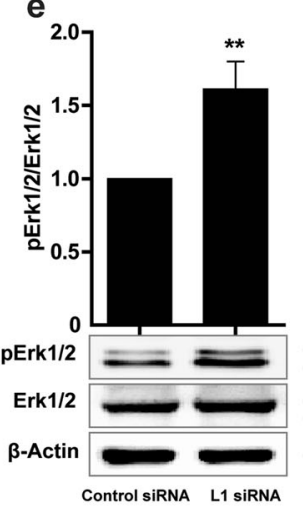

h

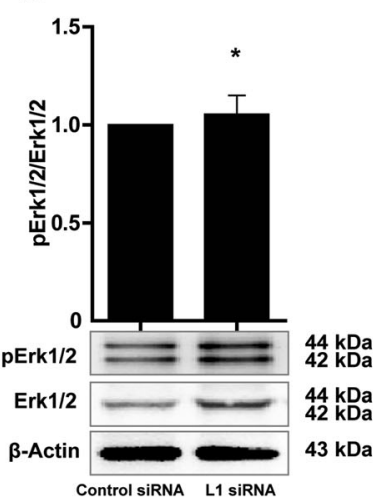

C

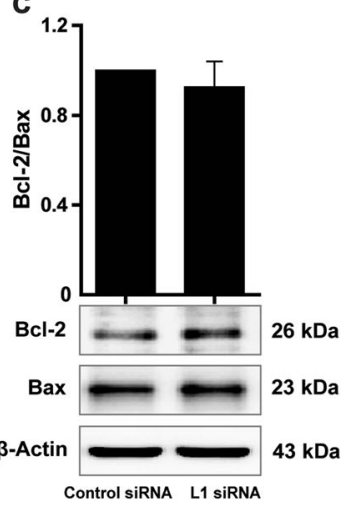

f

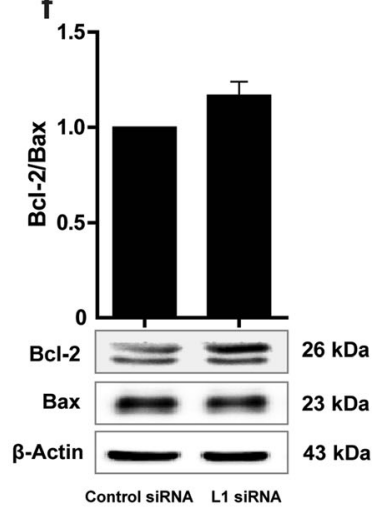

i

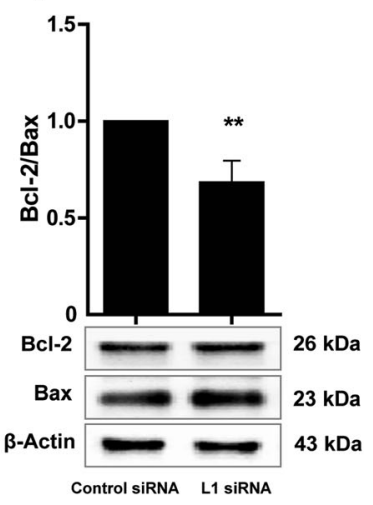

Fig. 4 Influence of L1 siRNA on apoptosis-related signaling pathways in glioma cells. Western blot analysis of expression levels of phosphorylated Akt1 $(\mathbf{a}, \mathbf{d}, \mathbf{g})$ and phosphorylated Erk1/2 (b, e, h), and ratio of Bcl-2/Bax (c, f, i) of U-87 MG, U251 and SHG44 cells after treatment with L1 siRNA. Mean values \pm SEM are from 4 independent experiments; one-way ANOVA with Tukey's post-hoc test. ${ }^{*} p<0.05$ and ${ }^{* *} p<0.001$ versus Control siRNA group

levels were also reduced by rL1 in U-87 MG cells (for 1 , $2.5,5$ and $10 \mathrm{nM}, p=0.059, p=0.001, p<0.000, p<0.000$, respectively, versus Control siRNA, Fig. 5c). In addition, pErk levels in U251 cell were dose-dependently increased by rL1 (for 1, 2.5, 5 and $10 \mathrm{nM}, p=0.455, p=0.332, p=$ 0.0145 , and $p=0.005$, respectively, versus Control siRNA, Fig. 5g). A similar pattern as for pAkt1 expression was seen for pErk1/2 in SHG44 cells, which peaked at $2.5 \mathrm{nM}$ of rL1 (for 1, 2.5, 5 and $10 \mathrm{nM}, p=0.003, p=0.031, p=$ 0.959 , and $p=0.221$, respectively, versus Control siRNA,
Fig. 5k). The $\mathrm{Bcl} 2 / \mathrm{Bax}$ ratio was reduced in response to rL1 treatment in U-87 MG cells at 2.5, 5, and $10 \mathrm{nM}(p=$ 0.733, $p=0.168, p=0.016, p=0.006$, respectively, versus Control siRNA, Fig. 5d). However, in U251 cells the ratio $\mathrm{Bcl} 2 / \mathrm{Bax}$ was increased at 1 and $2.5 \mathrm{nM}$, and decreased at 5 and $10 \mathrm{nM}$ (for 1, 2.5, 5 and $10 \mathrm{nM}, p=0.146, p=0.003$, $p=0.437$, and $p=0.023$, respectively, versus Control siRNA, Fig. 5h). Similarly, the ratio of Bcl2/Bax was increased at $1 \mathrm{nM}$ and decreased at 2.5, 5 and $10 \mathrm{nM}$ (for $1,2.5,5$ and $10 \mathrm{nM}, p=0.013, p=0.099, p=$ 


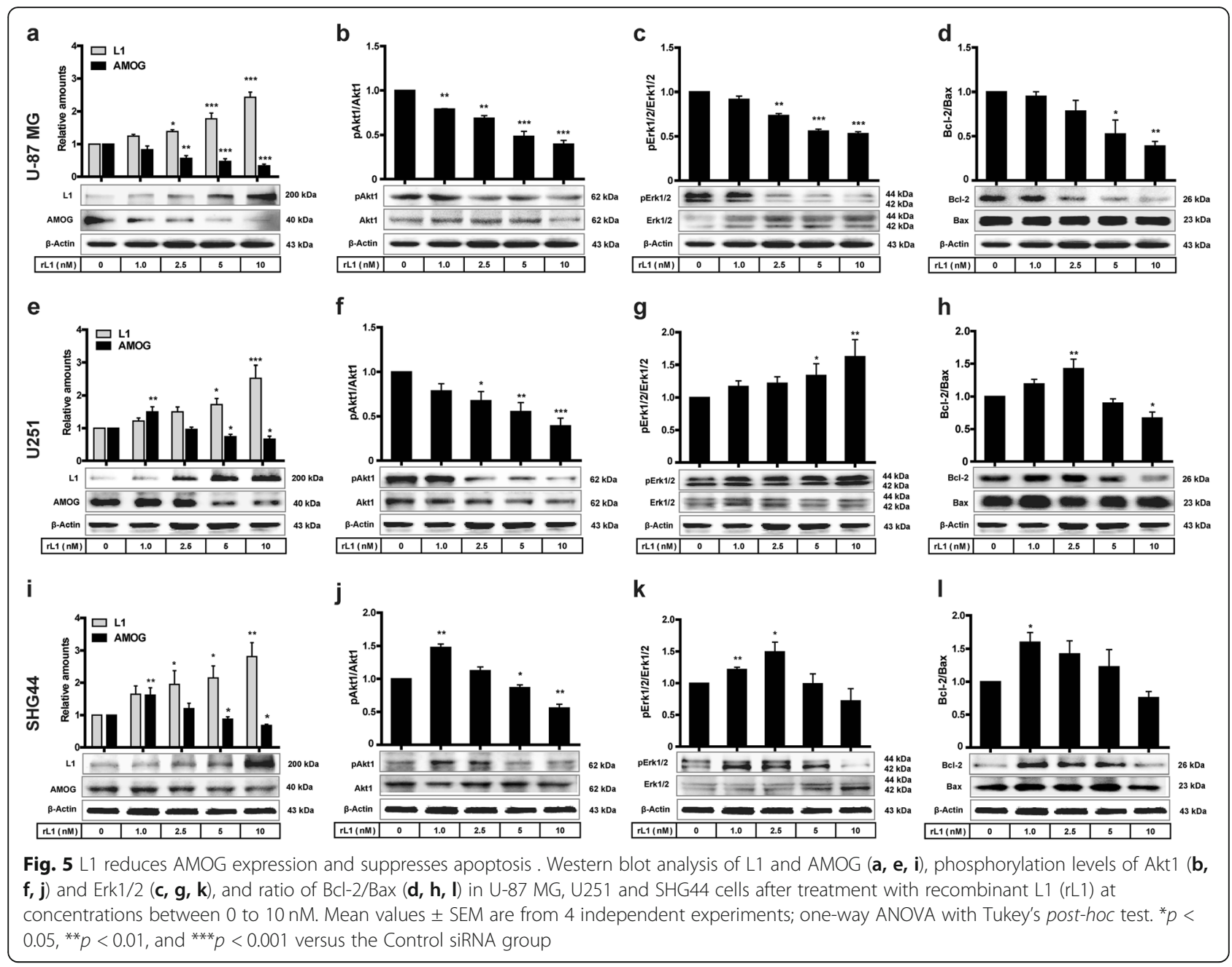

0.438 , and $p=0.057$, respectively, versus Control siRNA, Fig. 5i).

\section{Over-expression of AMOG reduces L1 expression and apoptosis-related signaling pathways}

To evaluate the role of AMOG on L1 expression and apoptosis, glioma cells were transfected with an AMOG encoding plasmid DNA. AMOG protein levels in U-87 MG and U251 cells were up-regulated $(p<0.000$ in U87 MG cells and $p=0.0588$ in U251 cells, all $p$ values refer to the Control plasmid DNA). In contrast, L1 levels were reduced when compared to the Control plasmid DNA group $(p<0.000$ in U-87 MG cells, $p=0.0043$ in U251 cells, Fig. 6a, e). Increased pAkt1 levels were seen in U-87 MG and U251 cells ( $p=0.003$ in U-87 MG cells and $p=0.0043$ in $\mathrm{U} 251$ cells, versus Control plasmid, Fig. 6b, f). Yet, levels of pErk $1 / 2$ were reduced in both cell lines in comparison to the Control plasmid group $(p=0.009$ in U-87 MG cells, $p=0.0435$ in U251 cells, Fig. 6c, g). Bcl-2/Bax ratios were reduced in response to AMOG over-expression when compared to the Control plasmid group $(p<0.000$ in U-87 MG cells and $p=$ 0.0199 in U251 cells, Fig. 6d, h). Of note, over-expression of AMOG in SHG44 cells led to their failure to adhere to the cell culture dish, thereby evoking cell death. The combined results suggest that AMOG is involved in glioma cell apoptosis by reducing L1 expression. These features again point to differences in the functional features of tumor cells.

\section{Discussion}

Gliomas have challenged researchers for decades with minimal progress towards an effective treatment due to the complexity of their cellular components, diffuse invasiveness and capacity to escape therapies [20-25]. Glial tumor cells express abnormal levels of cell adhesion molecules, highly correlating with the malignancy of these tumors [26-28]. Accordingly, cell surface and extracellular adhesion molecules have been studied for the management of invasive gliomas that mediate multiple cellular/molecular interactions and pathways [4, 29-33]. For instance, treatment with chimeric antigen receptors targeting L1 in 6 


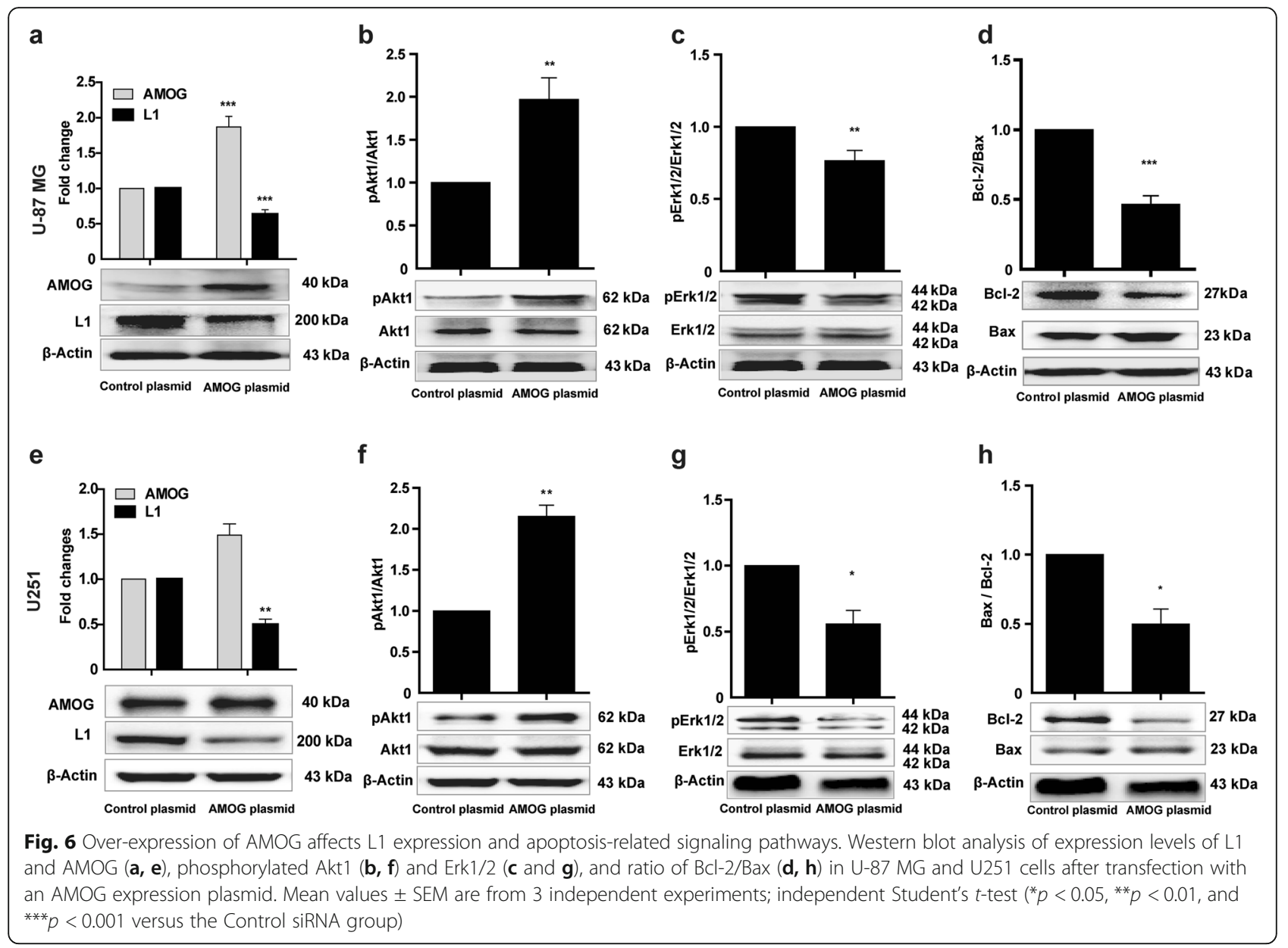

children with metastatic neuroblastoma via genetically engineered cytolytic T-lymphocytes allowed one patient to experience prolonged survival with a limited disease burden [34]. A recent study reported that L1 plays an essential role in initiating metastatic colonization in the spreading of disseminated cancer cells on capillaries, resulting in activation of Yes-associated protein (YAP) and myocardin-related transcription factor [35]. While L1-related in tumor malignancy has been well studied, relatively little is known about AMOG's functions in tumors, yet present knowledge indicates that AMOG is associated with glioma cell invasiveness and migration $[12,13]$. Thus, an understanding of the functional relationship between L1 and AMOG in glial tumors may offer new opportunities to develop specific and effective therapies.

In a previous investigation [36], using a microarray with the same catalogue, but different batch number, we had immunofluorescently demonstrated highest L1 levels in III and IV grade human glioma tissues and a positive correlation between the level of L1 expression and glioma grade: higher grade gliomas express less L1 than the lower grade gliomas. In the microarray used in the present study, AMOG expression was lowest in III and IV grade human glioma tissues and inversely correlated with the degree of tumor malignancy. Combining the previous with the present data suggests that AMOG inversely correlates with L1 expression. Thus, lower AMOG levels correlate with higher L1 levels in glioma cells, increasing with malignancy, and correlating with cell proliferation, survival, migration, invasion, and inhibition of apoptosis [4, 26, 30, 36]. Reduced expression of AMOG has been correlated with enhanced malignancy $[36,37]$, and raised the question about links of reciprocal influences in expression. We now show that reduction of AMOG expression in cultured glioblastoma cells leads to an increase in L1 expression and a decrease in apoptosis. Furthermore, both molecules are involved in regulating signal transduction mechanisms pertaining to apoptosis via Akt and Erk activation. Notably, AMOG subserves two functions: on the one hand, it is a recognition molecule and, on the other hand, it is part of the $\mathrm{Na}, \mathrm{K}$-ATPase and comprises the regulatory subunit of an important ion pump that depends on its function on this subunit [13, 37]. Further experiments are needed to allow interpretations of the influence of this pump activity on tumor progression and L1 expression. 
Cell senescence is a key process involved in preventing tumor growth, and cancer cells have been considered to lose the capacity to be senescent [38, 39]. Emerging evidence has progressively contributed to our understanding of the central role of senescence as one of the processes inhibiting tumorigenesis [40]. In the present study, we found that reduction of AMOG expression delays cell senescence in vitro, and low AMOG expression correlates with reduced cell death. At first sight, this finding would be difficult to explain since one would assume that reduction of this functionally pivotal pump activity would increase cell death because of the resulting disturbed homeostatic balance. However, one could argue that an abnormal ionic balance may activate a cellular emergency program that could prevent cell death at least on a short-term basis, which was measured in the culture paradigms used in this study. Another explanation could be that low expression of AMOG leads to a higher expression of L1 and since L1 promotes survival of neurons in vitro and in vivo [41-43], it is plausible to assume that a higher L1 expression would promote cell survival. Given a possible functional outcome of opposite survival mechanisms, we suggest that the L1 driven promotion of cell survival would be more powerful in the determination of cell survival than ionic imbalance. The contribution of other adhesion molecules in tumorigenesis [44-47] could yield insights into the interplay between L1 and AMOG expression. Furthermore, activation of Akt and Erk signaling pathways has been found to be essential for glioma cell proliferation and invasion, and is correlated with tumor progression [4852]. We noticed that $\mathrm{L} 1$ exerted differential effects on Akt and Erk activation in the three glioma lines. We had observed that U87-MG cells release large amounts of L1's extracellular domain, which can trans-homophilically interact with full length L1 at the tumor cell surface to initiate a series of functional events [15]. The endogenous soluble L1 from the tumor cell in combination with exogenously added L1 may reduce the activation Akt and Erk actication in U87-MG cells. In contrast, the less malignant SHG44 cells may generate less L1, so that the effects of exogenous L1 on Akt and Erk can be detected.

It will be interesting in the context of the relationship between L1 and AMOG to identify the receptors for AMOG in relation to the cognate receptors for L1. We suggest that the findings of the present study contribute to ongoing attempts to develop a molecularly targeted therapy for glioma management.

\section{Conclusions}

In conclusion, we show that AMOG expression is reduced in glioma cells with increasing malignancy, correlating inversely with L1 expression, which increases in expression with increasing malignancy. Down-regulation of AMOG expression induces cell senescence, which appears to be counteracted by increased L1 expression, which has been shown to enhance neuronal cell survival [53]. The mechanisms by which AMOG and L1 regulate their interactions remain unknown. It will thus be important to identify the receptors for AMOG, also in relation to the cognate receptors for L1. In addition, further investigations on interrelationships between cell adhesion molecules in tumorigenesis will be important to pursue.

\section{Additional files}

\begin{abstract}
Additional file 1: Figure S1. Reduction of $L 1$ expression increases AMOG expression. Western blot analysis of $\mathrm{L} 1$ and AMOG expression in U-87 MG (a), U251 (b), and SHG44 (c) cells after treatment with L1 siRNA at 10 and $20 \mathrm{nM}$. Mean values \pm SEM are from 4 independent experiments. ${ }^{*} p<0.05,{ }^{* *} p<0.01,{ }^{* * *} p<0.001$ vs. Control siRNA, independent Student's t-test). (TIF $2142 \mathrm{~kb}$ )

Additional file 2: Figure S2. Expression of AMOG in relation to L1. Representative images of double immunofluorescence staining of L1 and AMOG after treatment with L1 siRNA at 10 and $20 \mathrm{nM}$ in U-87 MG (a), U251 (b) and SHG44 (c) cells. Scale bars $=50 \mu \mathrm{m}$. (TIF $3736 \mathrm{~kb}$ )

Additional file 3: Figure S3. Apoptosis-related signaling pathways are affected by reduced $\mathrm{L} 1$ expression. Expression levels of phosphorylated Akt1 (a, d, g) and phosphorylated Erk1/2 (b,e, h), and ratio of Bcl-2/Bax $(\mathbf{c}, \mathbf{f}, \mathbf{i})$ in U-87 MG, U251 and SHG44 cells after treatment with either 10 or 20 nM L1 siRNA. Mean values \pm SEM are from 4 independent experiments. (One-way ANOVA with Tukey's post-hoc test. ${ }^{*} p<0.05$, ${ }^{* *} p<0.01$ and ${ }^{* *} p<0.001$ versus Control siRNA group). (TIF $2889 \mathrm{~kb}$ )
\end{abstract}

\section{Abbreviations}

Akt: Protein Kinase B; AMOG: Adhesion molecule on glia; ECL: Enhanced chemiluminescence; Erk: Extracellular signal-regulated kinases; L1: Neural cell adhesion molecule L1 (L1CAM); pAKT: phosphorylated Akt;

pErk: phosphorylated Erk; PI3K: Phosphoinositide 3-kinase; rL1: recombinant human L1CAM extracellular domain; RNAi: RNA interference; WHO: World Health Organization; YAP: Yes-associated protein

\section{Acknowledgments}

The authors are grateful to US native speaker Prof. Stanley Lin for professional editing.

\section{Authors' contributions}

All authors contributed intellectually and experimentally to this work. QJ conducted the experimental work, analyzed the data, prepared the figures and wrote a draft of the manuscript. QX, CH, ZY, PH, and HS assisted with maintenance of cell lines and organizing the availability of reagents. MS and WZ were responsible for the overall conception of the project, analysis of publicly available data and manuscript preparation. All authors have read the manuscript and agreed with the presentation of the manuscript.

\section{Funding}

This work was supported by the National Natural Science Foundation of China (grant nos. 81471279 and 81171138 to WJZ), Shantou University Medical College for a Talent Support Grant (grant no. 2501220118 to WJ. Z.) and Li Kashing Foundation (LD030601 to MS). The funding bodies had no role in the design of the study and collection, analysis, and interpretation of data and in writing the manuscript.

\section{Availability of data and materials}

The authors confirm that all data and materials are kept at Shantou University Medical College and please contact the corresponding author for all data requests.

Ethics approval and consent to participate Both human glioma tissue microarray and human glioma/glioblastoma cell lines are commercially available. 


\section{Consent for publication}

Not applicable.

\section{Competing interests}

The authors declare that they have no competing interests.

\section{Author details}

${ }^{1}$ Center for Neuroscience, Shantou University Medical College, 22 Xin Ling Road, Shantou, Guangdong 515041, People's Republic of China. ${ }^{2}$ Keck Center for Collaborative Neuroscience and Department of Cell Biology and Neuroscience, Rutgers University, 604 Allison Road, Piscataway, NJ 08854, USA.

Received: 6 March 2019 Accepted: 26 August 2019

Published online: 12 September 2019

\section{References}

1. Weller M, Wick W, Aldape K, Brada M, Berger M, Pfister SM, Nishikawa R, Rosenthal M, Wen PY, Stupp R. Glioma. Nat Rev Dis Primers. 2015;1:15040.

2. Rajesh Y, Pal I, Banik P, Chakraborty S, Borkar SA, Dey G, Mukherjee A, Mandal M. Insights into molecular therapy of glioma: current challenges and next generation blueprint. Acta Pharmacol Sin. 2017;38(5):591-613.

3. Antonicek $H$, Persohn $E$, Schachner M. Biochemical and functional characterization of a novel neuron-glia adhesion molecule that is involved in neuronal migration. J Cell Biol. 1987;104(6):1587-95.

4. Izumoto S, Ohnishi T, Arita N, Hiraga S, Taki T, Hayakawa T. Gene expression of neural cell adhesion molecule L1 in malignant gliomas and biological significance of L1 in glioma invasion. Cancer Res. 1996;56(6):1440-4.

5. Senner V, Kismann E, Puttmann S, Hoess N, Baur I, Paulus W. L1 expressed by glioma cells promotes adhesion but not migration. Glia. 2002;38(2):146-54

6. Kucherer A, Faissner A, Schachner M. The novel carbohydrate epitope $L 3$ is shared by some neural cell adhesion molecules. J Cell Biol. 1987;104(6): 1597-602.

7. Geering K, Theulaz I, Verrey F, Hauptle MT, Rossier BC. A role for the betasubunit in the expression of functional Na+-K+-ATPase in Xenopus oocytes. Am J Phys. 1989;257(5 Pt 1):C851-8.

8. Gloor S, Antonicek H, Sweadner KJ, Pagliusi S, Frank R, Moos M, Schachner $\mathrm{M}$. The adhesion molecule on glia (AMOG) is a homologue of the beta subunit of the Na,K-ATPase. J Cell Biol. 1990;110(1):165-74.

9. Magyar JP, Schachner M. Genomic structure of the adhesion molecule on glia (AMOG, Na/K-ATPase beta 2 subunit). Nucleic Acids Res. 1990; 18(22):6695-6

10. Pagliusi S, Antonicek H, Gloor S, Frank R, Moos M, Schachner M Identification of a cDNA clone specific for the neural cell adhesion molecule AMOG. J Neurosci Res. 1989;22(2):113-9.

11. Muller-Husmann G, Gloor S, Schachner M. Functional characterization of beta isoforms of murine Na,K-ATPase. The adhesion molecule on glia (AMOG/beta 2), but not beta 1, promotes neurite outgrowth. J Biol Chem. 1993:268(35):26260-7

12. Senner V, Schmidtpeter S, Braune S, Puttmann S, Thanos S, Bartsch U, Schachner M, Paulus W. AMOG/beta2 and glioma invasion: does loss of AMOG make tumour cells run amok? Neuropathol Appl Neurobiol. 2003;29(4):370-7.

13. Sun MZ, Kim JM, Oh MC, Safaee M, Kaur G, Clark AJ, Bloch O, Ivan ME, Kaur $\mathrm{R}, \mathrm{Oh} \mathrm{T}$, et al. $\mathrm{Na}(+) / \mathrm{K}(+)$-ATPase beta2-subunit (AMOG) expression abrogates invasion of glioblastoma-derived brain tumor-initiating cells. Neuro-oncology. 2013;15(11):1518-31.

14. Sytnyk V, Leshchyns'ka I, Schachner M. Neural cell adhesion molecules of the immunoglobulin superfamily regulate synapse formation, maintenance, and function. Trends Neurosci. 2017:40(5):295-308.

15. Zhao W. Comparison of $\mathrm{L} 1$ expression and secretion in glioblastoma and neuroblastoma cells. Oncol Lett. 2012;4(4):812-6.

16. García MA, Carrasco E, Ramírez A, Jiménez G, Lópezruiz E, Perán M, Picón M, Campos J, Boulaiz H, Marchal JA. Apoptosis as a therapeutic target in Cancer and Cancer stem cells: novel strategies and futures perspectives. Citeseer. 2012;30:87

17. Wong RS. Apoptosis in cancer: from pathogenesis to treatment. J Exp Clin Cancer Res. 2011;30(1):87

18. Wu CJ, Chen Z, Ullrich A, Greene MI, O'Rourke DM. Inhibition of EGFRmediated phosphoinositide-3-OH kinase (PI3-K) signaling and glioblastoma phenotype by signal-regulatory proteins (SIRPs). Oncogene. 2000;19(35): 3999-4010.

19. Plossl K, Straub K, Schmid V, Strunz F, Wild J, Merkl R, Weber BHF, Friedrich $\mathrm{U}$. Identification of the retinoschisin-binding site on the retinal $\mathrm{Na} / \mathrm{K}$-ATPase. PLoS One. 2019;14(5):e0216320.

20. Sathornsumetee S, Rich JN, Reardon DA. Diagnosis and treatment of highgrade astrocytoma. Neurol Clin. 2007;25(4):1111-39.

21. Omuro A, DeAngelis LM. Glioblastoma and other malignant gliomas: a clinical review. Jama. 2013;310(17):1842-50.

22. Kuijlen JM, Bremer E, Mooij JJ, den Dunnen WF, Helfrich W. Review: on TRAIL for malignant glioma therapy? Neuropathol Appl Neurobiol. 2010;36(3):168-82.

23. Mladkova N, Chakravarti A. Molecular profiling in glioblastoma: prelude to personalized treatment. Curr Oncol Rep. 2009;11(1):53-61.

24. Chen R, Cohen AL, Colman H. Targeted therapeutics in patients with high-grade gliomas: past, present, and future. Curr Treat Options in Oncol. 2016;17(8):42.

25. Tysnes BB, Mahesparan R. Biological mechanisms of glioma invasion and potential therapeutic targets. J Neuro-Oncol. 2001;53(2):129-47.

26. Gingras MC, Roussel E, Bruner JM, Branch CD, Moser RP. Comparison of cell adhesion molecule expression between glioblastoma multiforme and autologous normal brain tissue. J Neuroimmunol. 1995;57(1-2):143-53.

27. Shimizu T, Kurozumi K, Ishida J, Ichikawa T, Date I. Adhesion molecules and the extracellular matrix as drug targets for glioma. Brain Tumor Pathol. 2016; 33(2):97-106.

28. Salmaggi A, Eoli M, Frigerio S, Ciusani E, Silvani A, Boiardi A. Circulating intercellular adhesion molecule-1 (ICAM-1), vascular cell adhesion molecule1 (VCAM-1) and plasma thrombomodulin levels in glioblastoma patients. Cancer Lett. 1999:146(2):169-72.

29. Bao S, Wu Q, Li Z, Sathornsumetee S, Wang H, McLendon RE, Hjelmeland $A B$, Rich JN. Targeting cancer stem cells through L1CAM suppresses glioma growth. Cancer Res. 2008;68(15):6043-8.

30. Cheng L, Wu Q, Guryanova OA, Huang Z, Huang Q, Rich JN, Bao S. Elevated invasive potential of glioblastoma stem cells. Biochem Biophys Res Commun. 2011:406(4):643-8.

31. Skibbens RV. Chl1p, a DNA helicase-like protein in budding yeast, functions in sister-chromatid cohesion. Genetics. 2004;166(1):33-42.

32. Wolterink S, Moldenhauer G, Fogel M, Kiefel H, Pfeifer M, Luttgau S, Gouveia R, Costa J, Endell J, Moebius U, et al. Therapeutic antibodies to human L1CAM: functional characterization and application in a mouse model for ovarian carcinoma. Cancer Res. 2010;70(6):2504-15.

33. Couldwell WT, de Tribolet N, Antel JP, Gauthier T, Kuppner MC. Adhesion molecules and malignant gliomas: implications for tumorigenesis. J Neurosurg. 1992;76(5):782-91.

34. Park JR, Digiusto DL, Slovak M, Wright C, Naranjo A, Wagner J, Meechoovet $H B$, Bautista C, Chang WC, Ostberg JR, et al. Adoptive transfer of chimeric antigen receptor re-directed cytolytic T lymphocyte clones in patients with neuroblastoma. Mol Ther. 2007;15(4):825-33.

35. Er EE, Valiente M, Ganesh K, Zou Y, Agrawal S, Hu J, Griscom B, Rosenblum M, Boire A, Brogi E, et al. Pericyte-like spreading by disseminated cancer cells activates YAP and MRTF for metastatic colonization. Nat Cell Biol. 2018;20(8):966-78.

36. Zhao WJ, Schachner M. Neuregulin 1 enhances cell adhesion molecule 11 expression in human glioma cells and promotes their migration as a function of malignancy. J Neuropathol Exp Neurol. 2013;72(3):244-55.

37. Rotoli D, Cejas MM, Maeso MD, Perez-Rodriguez ND, Morales M, Avila J, Mobasheri A, Martin-Vasallo P. The Na, K-ATPase beta-subunit isoforms expression in glioblastoma Multiforme: moonlighting roles. Int J Mol Sci. 2017;18(11):2369.

38. Hale AJ, Smith CA, Sutherland LC, Stoneman VE, Longthorne V, Culhane AC, Williams GT. Apoptosis: molecular regulation of cell death. Eur J Biochem. 1996:237(3):884.

39. Campisi J, d'Adda di Fagagna F. Cellular senescence: when bad things happen to good cells. Nat Rev Mol Cell Biol. 2007;8(9):729-40.

40. Wu CH, van Riggelen J, Yetil A, Fan AC, Bachireddy P, Felsher DW. Cellular senescence is an important mechanism of tumor regression upon c-Myc inactivation. Proc Natl Acad Sci U S A. 2007;104(32):13028-33.

41. Milstone AM, Bamford P, Aucott SW, Tang N, White KR, Bearer CF. Chlorhexidine inhibits L1 cell adhesion molecule-mediated neurite outgrowth in vitro. Pediatr Res. 2014;75(1-1):8-13.

42. Lutz D, Loers G, Kleene R, Oezen I, Kataria H, Katagihallimath N, Braren I, Harauz G, Schachner M. Myelin basic protein cleaves cell adhesion molecule L1 and promotes neuritogenesis and cell survival. J Biol Chem. 2014;289(19):13503-18. 
43. Guseva D, Loers G, Schachner M. Function-triggering antibodies to the adhesion molecule L1 enhance recovery after injury of the adult mouse femoral nerve. PLoS One. 2014;9(11):e112984.

44. Cavallaro U, Christofori G. Cell adhesion and signalling by cadherins and IgCAMs in cancer. Nat Rev Cancer. 2004;4(2):118-32.

45. Samatov TR, Wicklein D, Tonevitsky AG. L1CAM: cell adhesion and more. Prog Histochem Cytochem. 2016;51(2):25-32.

46. Altevogt P, Doberstein K, Fogel M. L1CAM in human cancer. Int J Cancer. 2016;138(7):1565-76

47. Kiefel H, Bondong S, Hazin J, Ridinger J, Schirmer U, Riedle S, Altevogt P. L1CAM: a major driver for tumor cell invasion and motility. Cell Adhes Migr. 2012;6(4):374-84.

48. Sebolt-Leopold JS, Herrera R. Targeting the mitogen-activated protein kinase cascade to treat cancer. Nat Rev Cancer. 2004;4(12):937-47.

49. Nakada M, Kita D, Furuta T, Watanabe T, Hayashi Y, Hamada Jl. Signaling cascades driving the malignant phenotype of glioma cells. Vienna: Springer; 2014.

50. Ren HP, Yin XY, Yu HY, Xiao HF. Stevioside induced cytotoxicity in colon cancer cells via reactive oxygen species and mitogen-activated protein kinase signaling pathways-mediated apoptosis. Oncol Lett. 2017;13(4):2337-43.

51. Scheidenhelm DK, Cresswell J, Haipek CA, Fleming TP, Mercer RW, Gutmann DH. Akt-dependent cell size regulation by the adhesion molecule on glia occurs independently of phosphatidylinositol 3-kinase and Rheb signaling. Mol Cell Biol. 2005;25(8):3151-62.

52. Cavallaro U, Dejana E. Adhesion molecule signalling: not always a sticky business. Nat Rev Mol Cell Biol. 2011;12(3):189-97.

53. Wang $Y$, Schachner $M$. The intracellular domain of L1CAM binds to casein kinase 2alpha and is neuroprotective via inhibition of the tumor suppressors PTEN and p53. J Neurochem. 2015;133(6):828-43.

\section{Publisher's Note}

Springer Nature remains neutral with regard to jurisdictional claims in published maps and institutional affiliations.

Ready to submit your research? Choose BMC and benefit from:

- fast, convenient online submission

- thorough peer review by experienced researchers in your field

- rapid publication on acceptance

- support for research data, including large and complex data types

- gold Open Access which fosters wider collaboration and increased citations

- maximum visibility for your research: over $100 \mathrm{M}$ website views per year

At $\mathrm{BMC}$, research is always in progress.

Learn more biomedcentral.com/submissions 